\section{Clare Hall: a New Development of Clare College, Cambridge}

Clare College has decided to promote within the College a new development to be known as Clare Hall. The intention is that Clare Hall shall make a contribution towards moeting present-day Cambridge needs by providing a new graduate society for resident and visiting scholars. Its fellowship is designed to bring together four categories: (1) scholars holding appointments in the University or in research institutions in Cambridge, whose subjects may not be in great demand for undorgraduate teaching; (2) post-doctoral and other senior research workers; (3) visiting scholars in Cambridge on study-leave; (4) Research Follows, elected from among more senior research studonts. When the new society has been establishod, a body of research students who are not Follows will be added. The University has a petition before the Queen-in-Council, asking for a repeal of the University Statute which oxcludes women from membership of men's Colleges. Subject to approval being given to this petition, fellowships in Clare Hall will be open to men and women on equal terms. Clare Hall will be legally part of Clare College, governod by statutos of the College. The Society will consist of about forty Fellows of Clere Hall, who will also be bye-Follows of Clare College. It will be governed by a Council composed of five Fellows of the Hall, five Fellows of the College, the Warden of the Hall, and the Master of the College as chairman. It is proposed that the buildings for Clare Hall, which will include flats, studies, a seminar room, and dining rooms, will be on a site within five minutos' walk of Clare College, where the Hall will be able to devolop an identity of its own and to maintain, socially and intellectually, a close relationship with the College.

The Governing Body has recorded its intention to elect into fellowships of Clare Hall and bye-fellowships of Clare College the following: Dr. T. E. Armstrong, Mr. R. W. David, Mr. E. P. M. Dronke, Miss M. B. Hesse, and Dr. W. H. Taylor.

Clare College has received from the Old Dominion Foundation of New York an endowment of 200,000 dollars. The income from the endowment will be used to subsidize research fellowships and visiting fellowships at Clare Hall.

\section{The Night Sky in August}

New moon occurs on Aug. 7d $19 \mathrm{~h} 17 \mathrm{~m}$ U.T. and full moon on Aug. $23 \mathrm{~d} 05 \mathrm{~h} 26 \mathrm{~m}$. The following conjunctions with the Moon occur: Aug. 2d 03h, Jupiter $2^{\circ} \mathrm{N}$.; Aug. $4 \mathrm{~d} 16 \mathrm{~h}$, Venus $5^{\circ} \mathrm{S}$.; Aug. $4 \mathrm{~d}$ 23h, Mars 0.2 $2^{\circ}$.; Aug. $23 \mathrm{~d} 07 \mathrm{~h}$, Saturn $3^{\circ}$ N.; Aug. $29 \mathrm{~d} 13 \mathrm{~h}$, Jupiter $2^{\circ} \mathrm{N}$. Venus is in conjunction with Mars on Aug. 28d $11 \mathrm{~h}$, Venus being $4^{\circ} \mathrm{S}$. Mercury is too close to the Sun for observation. Venus is a morning star, rising at $1 \mathrm{~h} 25 \mathrm{~m}, 1 \mathrm{~h} 5 \mathrm{~m}$ and $1 \mathrm{~h} 10 \mathrm{~m}$ on August 1,15 and 31 , respectively. Its stellar magnitude is $-4 \cdot 1$; its distance from the Earth increases during the month from 46 to 67 million miles and the visible portion of the apparent disk from 0.320 to 0.516 . Mars rises at $1 \mathrm{~h} 05 \mathrm{~m}, 0 \mathrm{~h} 50 \mathrm{~m}$ and $0 \mathrm{~h} 35 \mathrm{~m}$ at the beginning, middle and end of the month, respectively. Its stellar magnitude is $+1 \cdot 7$; conditions for observation are not yet favourablo. Jupiter rises at $23 \mathrm{~h} 05 \mathrm{~m}, 22 \mathrm{~h} 15 \mathrm{~m}$ and $21 \mathrm{~h} 15 \mathrm{~m}$ on August 1,15 and 31 , respectively. It is near the boundary of Aries and Taurus, its stellar magnitude is $-2 \cdot 0$ and its distance from the Earth on August 15 is 456 million miles. Saturn is above the horizon most of the night. It is in Aquarius and in opposition on August 24. Its stellar magnitude is +0.6 and its distance from the Earth on August 15 is 816 million miles. Occultations of stars brighter than magnitude 6 are as follows, observations boing made at Greenwich: Aug. $22 \mathrm{~d} 00 \mathrm{~h} 24 \cdot 2 \mathrm{~m}$, $\varnothing$ Cap. (disappearance); Aug. 28d 23h 18.2m, 147 B. Ari. (reappearance). The Perseid meteors are active during July 27-August 17, with maximum on August 12. The radiant is near R.A. $3 \mathrm{~h} 04 \mathrm{~m}$, Dec. $+58^{\circ}$; conditions for observation are very favourable.

\section{Announcements}

Prof. Paul Phillips, of the University of Wisconsin, Madison, Wis., has been awarded a "medal of merit" by the Istituto Sperimentale "L. Spallanzani", Milan, in recognition of his contributions to the development of a practical method for artificially inseminating cows and for research on mineral olements in nutrition.

Tre New Zealand Department of Scientific and Industrial Research has issued a list of printed publications, indicating those out of print and where those still in print can be obtained; more than 70 are publications of the Geological Survey and more than 150 Research Bulletins of the Department (List of Publications. Pp. 35. Wellington: Government Printer, 1964).

A CONFERENCE on "The Use of Film in Higher Education and Research" will be held at the College of Advanced Tochnology, Birmingham, during Septomber 9-11. Further information can be obtained from P. D. Groves, Dopartment of Chemistry, College of Advanced Technology, Gosta Green, Birmingham 4.

A series of lectures on "Plasma Physics and its Applications in the Field of Thermo-nuclear Reactions and Electrical Powor Generation" will bo hold at Sunderland Technical College during September 8-11. Further information can be obtained from the Physies Department, Sunderland Technical College, Sunderland.

A Course on "The Genotics and Physiology of Bacterial Viruses" will be held under the auspices of Unesco and the International Cell Research Organization, at the International Laboratory of Genetics and Biophysies, Naplos, during September 11-October 9. Further information can be obtained from the International Laboratory of Genetics and Biophysies, Casella Postale 104, Naples.

THE fifth international symposium on "Gas Chromatography", organized by the Gas Chromatography Discussion Group of the Institute of Petroleum, will be held in Brighton during September 8-10. The programme will include sessions on: techniques of separation and identification; column design; oxploitation of molecular interactions. Furthor information can be obtained from the Organizing Office, Fifth International Symposium on Gas Chromatography, 61 New Cavendish Street, London, W.1.

A sectional meeting of the World Power Conforence on "The Struggle against Losses in the Field of Energy Economies" will bo held in Lausanne during September 13-17. The general themo of the meeting will be divided into the following sections: general aspocts; avoidance of losses in conversion; avoidance of losses in fuel transport and power transmission; avoidance of losses in utilization of energy. Further information can be obtained from the Swiss National Committee, World Power Conference, Plaza B, Petit Chêne 38, Lausanne.

THE fifteenth intornational Astronautical Congross will be held in Warsaw during September 7-12. The programme will include sessions on: flight programmes; propulsion techniques; navigation; lunar international laboratory; bioastronautics; powor systems for space vehicles; celestial mechanies and astrodynamics; physical problems of re-entry into planetary atmosphere; moteorological satellite systems; communication satellite systems; geodetic satellite systems; ground installations; education in astronautics; space vohicles in an ionized medium. Further information can be obtained from the International Astronautical Foderation, 250 rue SaintJacques, Paris 5. 